\title{
Successful Adjuvant Alternative Treatment with Saireito (Japanese Herbal Medicine) for Nodulocystic Acne
}

\section{Ichiro Kurokawa}

Department of Dermatology, Meiwa Hospital, Nishinomiya, Japan

\begin{abstract}
Nodulocystic acne is a type of refractory acne. Patients with nodulocystic acne in this study were treated with oral Saireito (Japanese herbal medicine) and concomitant drugs. The efficacy superior to "good" response was 84.0\%. Mild adverse reactions consisting of slightly elevated liver enzymes in two patients or hand and foot tremors were observed in one patient. Sinus tract and hypertrophic scar were remarkably improved in one patient. Our observations suggest that Saireito is a candidate adjuvant alternative for the treatment of nodulocystic acne. Further investigation is needed to elucidate the pharmacological mechanism and clinical effects of Saireito alone and acne pathogenesis.
\end{abstract}

Keywords: Nodulocystic acne; Saireito; Pathogenesis; Traditional Japanese herb

\section{Introduction}

Nodulocystic acne is a therapy-resistant type of acne for which oral isotretinoin has been used in the USA and Europe [1-2]. Treatment guideline for acne vulgaris was published by the Japanese Dermatological Association (JDA) in 2016 [3]. Although it described the treatment for a few nodules or subcutaneous induration, it did not address nodulocystic acne.

The JDA guideline recommends treating inflammatory cysts/ subcutaneous induration with oral antimicrobials such as tosfloxacin and tetracyclines identified as $\mathrm{C} 1$ (recommended option). However, cysts and subcutaneous induration without inflammation are not described [3]. Intralesional topical corticosteroid injection is recommended as B (recommended) treatments for cystic acne [3]. However, extravasations of corticosteroid from cyst outward may induce atrophic scar [3]. Therefore, nodulocystic acne is not easy to treat in Japan.

In Japan, isotretinoin is not available for the treatment of acne. Saireito, a traditional Japanese herb, has multiple effects including an intrinsic corticosteroid-like effect, inhibition of fibroblast proliferation, inhibition of reactive oxygen species production, inhibition of coagulation, inhibition of macrophage and neutrophil infiltration, and inhibition of endothelial cell activation. Thus, Saireito can inhibit granulomatous lesions. In this study, Saireito was administered to treat nodulocystic acne.

\section{Materials and Methods}

Nodulocystic acne was clinically defined as more than five nodules or cysts on the face. Nodules and cysts are defined as those $>5 \mathrm{~mm}$ in diameter.

Twenty-five patients with nodulocystic acne were enrolled in the study and orally administered Saireito $8.1 \mathrm{~g} /$ day $(4.05 \mathrm{~g} \times 2$ times/day) (Kracie Holdings. Ltd. Tokyo, Japan) for 12 weeks. The administration of oral antimicrobials, tranilast, and topical benzoyl peroxide (BPO) formulations and antimicrobials were also allowed. Clinical efficacy was evaluated as the number of nodules and cysts in 1-month intervals. The effectiveness was evaluated by an investigator's global improvement rating on a five-point scale. Scores were rated as follows: 4 (excellent), 75-100\%; 3 (good), 50-75\%; 2 (fair), 25-49\%; 1 (poor), 1-25\%; and 0 (none or worse). Adverse reactions were evaluated by clinical symptoms and blood examinations during treatment. Institutional review boards approved the study protocol.

\section{Results}

A summary of the results is shown in Table 1 .

\section{Background}

Twenty-one male patients and four female patients (mean age, 22.4 years; range, 12-41 years) were enrolled in this study. Of them, three also had rosacea.

\section{Concomitant drugs}

Oral antimicrobials included minocycline (MINO) (15 cases), faropenem (FRPN) (five cases), roxithromycin (RXM) (three cases), and clarithromycin (CAM) (one case). Oral tranilast was administered in two cases. Topical drugs included 3\% Benzoyl peroxide (BPO)/1\% clindamycin (CLDM) (15 cases), 2.5\% BPO (nine cases), ozenoxacin (OZNX) (two cases), and adapalene/2.5\% BPO (one case). Comedo extractions were performed in five cases. Incision and drainage was performed in three cases.

Most of the patients with nodulocystic acne responded to treatment with oral Saireito. After 12 weeks, an "Excellent" response was observed in 16 cases $(64 \%)$, "Good" in five $(20 \%)$, "Fair" in one $(4 \%)$, "Poor" in two (8\%), and "Not evaluated" in one (4\%). The efficacy rate superior to "Good" response was $84 \%$ ( 21 cases). Score for improvement showed 2.76 (4 weeks), 3.17 (8 weeks) and 3.42 (12 weeks).

In Case 1, multiple nodulocystic lesions were observed on the face (Figure 1). After treatment with Saireito, oral roxithromycin and topical BPO/CLDM for 3 months, the nodulocystic lesions subsided remarkably (Figure 2). In Case 20, numerous nodulocystic lesions

*Corresponding author: Ichiro Kurokawa M.D, Department of Dermatology, Acne Clinical Research Center, Nishinomiya, Japan, Tel: +81-798-47-1767; E-mail: kurokawa.i@meiwa-hospital.com

Received July 19, 2017; Accepted August 03, 2017; Published August 30, 2017 Citation: Kurokawa I (2017) Successful Adjuvant Alternative Treatment with Saireito (Japanese Herbal Medicine) for Nodulocystic Acne. J Nutr Disorders Ther 7: 215. doi: 10.4172/2161- 0509.1000215

Copyright: @ 2017 Kurokawa I. This is an open-access article distributed under the terms of the Creative Commons Attribution License, which permits unrestricted use, distribution, and reproduction in any medium, provided the original author and source are credited. 
Citation: Kurokawa I (2017) Successful Adjuvant Alternative Treatment with Saireito (Japanese Herbal Medicine) for Nodulocystic Acne. J Nutr Disorders Ther 7: 215. doi: 10.4172/2161- 0509.1000215

Page 2 of 5

\begin{tabular}{|c|c|c|c|c|c|c|c|c|c|c|c|c|}
\hline No. & Age & Gender & $4 w$ & $8 w$ & $12 w$ & $\begin{array}{l}\text { End } \\
\text { point }\end{array}$ & $\begin{array}{l}\text { Concomitant } \\
\text { drugs (oral) }\end{array}$ & $\begin{array}{l}\text { Concomitant drugs } \\
\text { (topical) }\end{array}$ & & $\begin{array}{c}\text { Blood } \\
\text { examination }\end{array}$ & Complication & Adverse reaction \\
\hline 1 & 41 & male & 4 & 4 & 4 & 4 & RXM & BPO & & WNL & & \\
\hline 2 & 21 & male & 2 & 3 & 4 & 4 & FRPN & BPO, OZNX & & WNL & & \\
\hline 3 & 18 & male & 3 & 4 & 4 & 4 & MINO & BPO, OZNX & comedo extraction & WNL & & \\
\hline 4 & 20 & male & 2 & 2 & 3 & 3 & MINO & BPO/CLDM, Heparinoid & & & & \\
\hline 5 & 29 & male & 3 & 3 & 4 & 4 & MINO & BPO/CLDM & & & & \\
\hline 6 & 20 & male & 1 & 1 & 1 & 1 & CAM & BPO/CLDM, BPO & & $\mathrm{ALT} \uparrow$ & & \\
\hline 7 & 20 & male & 1 & 1 & 1 & 1 & MINO & BPO/CLDM & comedo extraction & & & \\
\hline 8 & 16 & male & 3 & 3 & 3 & 3 & $\begin{array}{l}\text { MINO } \\
\text { FRPN }\end{array}$ & BPO & $\begin{array}{l}\text { incision, drainage, } \\
\text { comedo extraction }\end{array}$ & & & \\
\hline 9 & 14 & male & 3 & 3 & 4 & 4 & $\begin{array}{l}\text { MINO } \\
\text { FRPN }\end{array}$ & $\mathrm{BPO}$ & $\begin{array}{l}\text { incision, drainage, } \\
\text { comedo extraction }\end{array}$ & WNL & & \\
\hline 10 & 16 & male & 3 & 3 & 4 & 4 & MINO & BPO & $\begin{array}{l}\text { incision, drainage, } \\
\text { comedo extraction }\end{array}$ & WNL & & \\
\hline 11 & 19 & female & 3 & \multicolumn{2}{|c|}{ discontinued } & & & & & WNL & & tremor of hand and foot \\
\hline 12 & 20 & female & 2 & 2 & 2 & 2 & MINO & BPO/CLDM & & & & \\
\hline 13 & 34 & female & 3 & 3 & 3 & 3 & MINO & BPO/CLDM & & WNL & $\begin{array}{c}\text { rosacea } \\
\text { (rhinophyma) }\end{array}$ & \\
\hline 14 & 18 & male & 4 & 4 & 4 & 4 & MINO & BPO/CLDM & & WNL & rosacea & \\
\hline 15 & 18 & male & 3 & 4 & 4 & 4 & MINO & BPO/CLDM & & WNL & & \\
\hline 16 & 30 & male & 3 & 4 & 4 & 4 & $\mathrm{RXM}$ & BPO & & WNL & & \\
\hline 17 & 22 & male & 3 & 4 & 4 & 4 & FRPN & BPO & & & & \\
\hline 18 & 20 & male & 3 & 4 & 4 & 4 & $\begin{array}{l}\text { FRPN, } \\
\text { tranilast }\end{array}$ & BPO/CLDM & & & & \\
\hline 19 & 20 & male & 3 & 4 & 4 & 4 & MINO & BPO/CLDM & & $\mathrm{ALT} \uparrow$ & & \\
\hline 20 & 20 & male & 3 & 4 & 4 & 4 & MINO & BPO/CLDM & & & & \\
\hline 21 & 28 & male & 3 & 4 & 4 & 4 & MINO & BPO/CLDM & & & & \\
\hline 22 & 19 & male & 3 & 3 & 3 & 3 & tranilast & BPO/CLDM & & & & \\
\hline 23 & 21 & female & 4 & 4 & 4 & 4 & MINO & BPO/CLDM & & WNL & & \\
\hline 24 & 21 & male & 3 & 4 & 4 & 4 & & BPO/CLDM & & WNL & & \\
\hline \multirow[t]{2}{*}{25} & 34 & male & 1 & 1 & 2 & 3 & $\mathrm{RXM}$ & BPO/Adapalen & & WNL & & \\
\hline & 22.4 & & 2.76 & 3.17 & 3.42 & 3.46 & & & & & & \\
\hline
\end{tabular}

Table 1: Summary of cases with nodulocystic acne: background, sex, age, improvement score, concomitant drugs, other treatments, blood examination, complications, and adverse reactions.MINO:minocycline; RXM:roxythromycin; FRPN:faropenem; CAM:clarithromycin; BPO:benzoyl peroxide; ALT: alanine transferase; WNL:within normal limits.

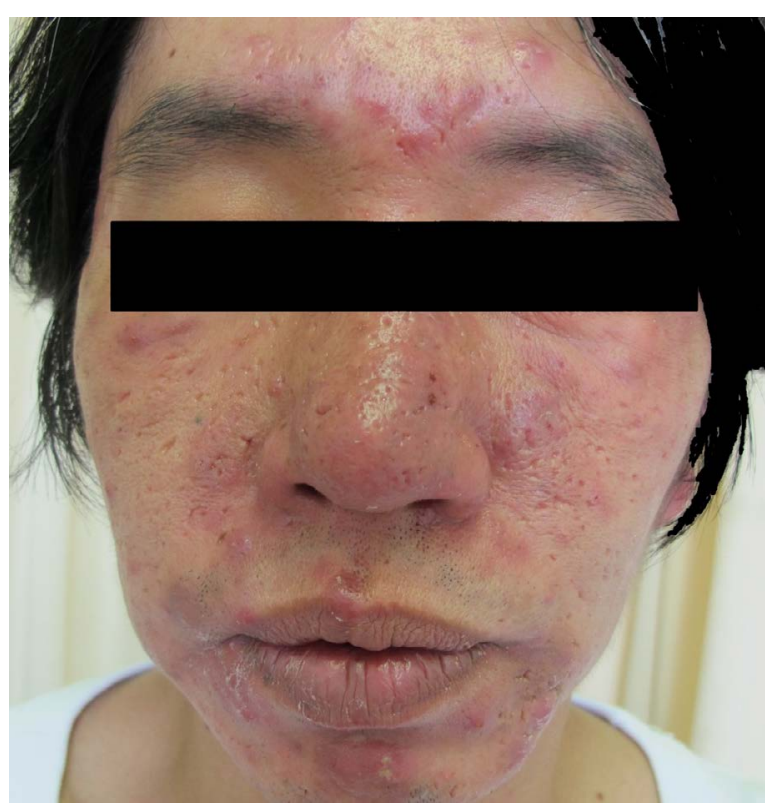

Figure 1: Multiple nodulocystic lesions were observed on the face (Case 1).

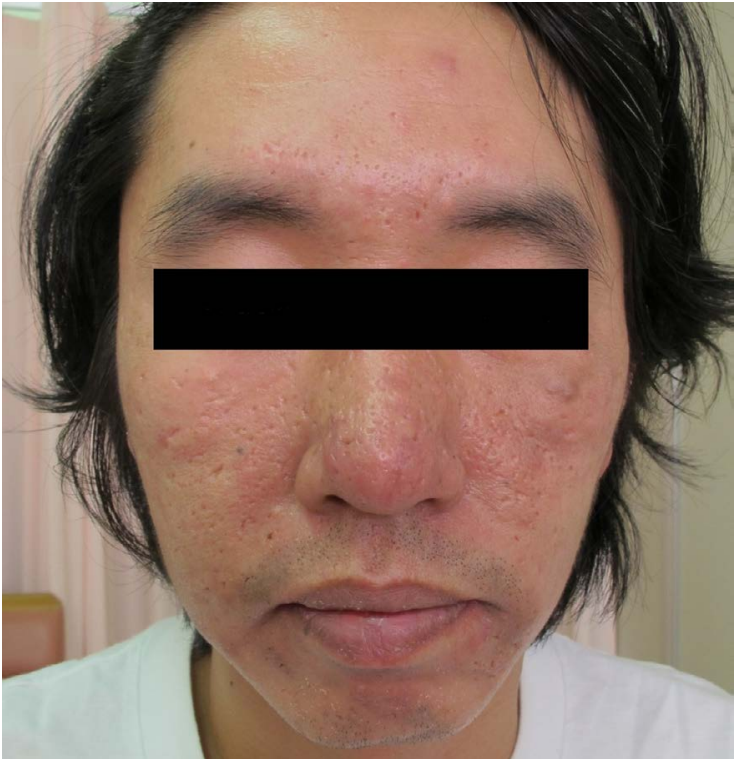

Figure 2: After treatment with Saireito, oral roxithromycin, and topical benzoyl peroxide/clindamycin for 3 months, the nodulocystic lesions subsided remarkably (Case 1 ). 
Citation: Kurokawa I (2017) Successful Adjuvant Alternative Treatment with Saireito (Japanese Herbal Medicine) for Nodulocystic Acne. J Nutr Disorders Ther 7: 215. doi: 10.4172/2161- 0509.1000215

with rosacea were observed on the face with erythema (Figure 3). After treatment with oral Saireito, minocycline and topical BPO/ CLDM for 3 months, nodulocystic lesions and erythema disappeared almost completely (Figure 4). Additionally, a sinus fistula was observed on the postauricular area in Case 20 before treatment (Figure 5), but disappeared completely after treatment (Figure 6). Elevated multiple hypertrophic scars with redness were observed on the neck in Case 15 (Figure 7). After the treatment, the hypertrophic scars had improved remarkably (Figure 8). Erythema with rosacea in three cases subsided after the treatment.

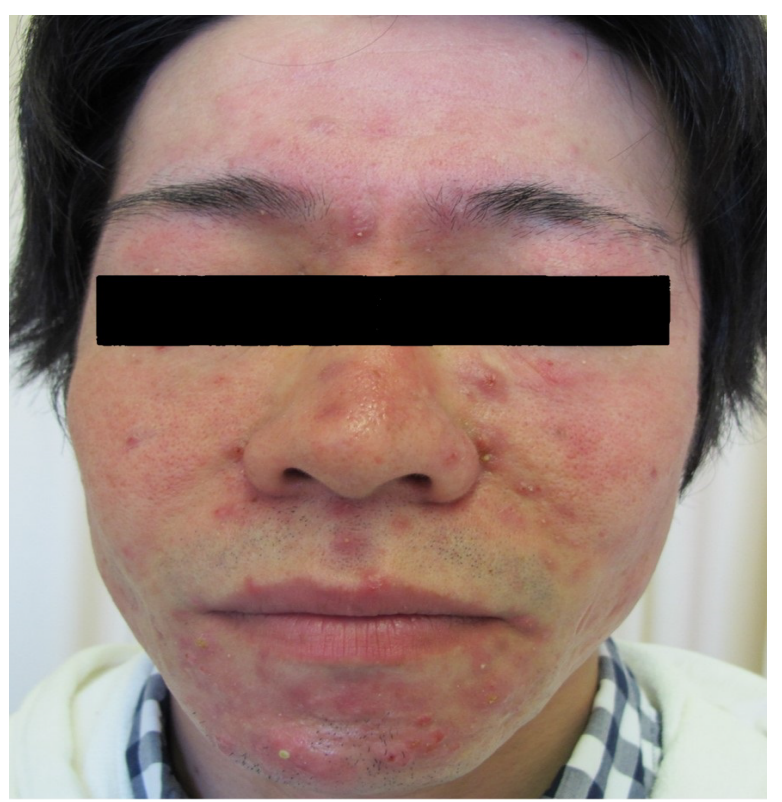

Figure 3: Numerous nodulocystic lesions with erythema were observed on the face (Case 20).

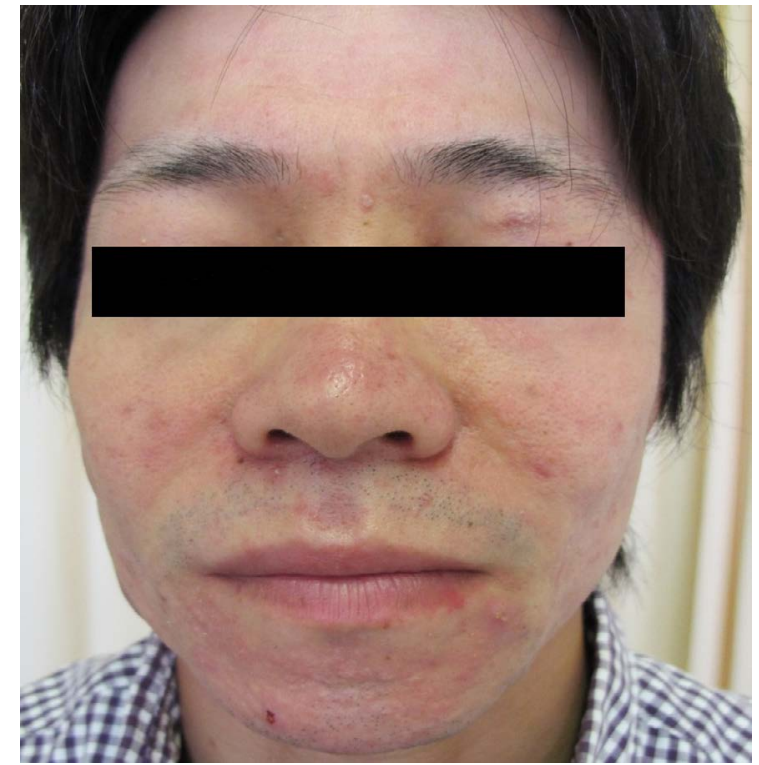

Figure 4: After treatment with oral Saireito, minocycline and topical benzoyl peroxide/clindamycin for 3 months, the nodulocystic lesions and erythema disappeared almost completely (Case 20).

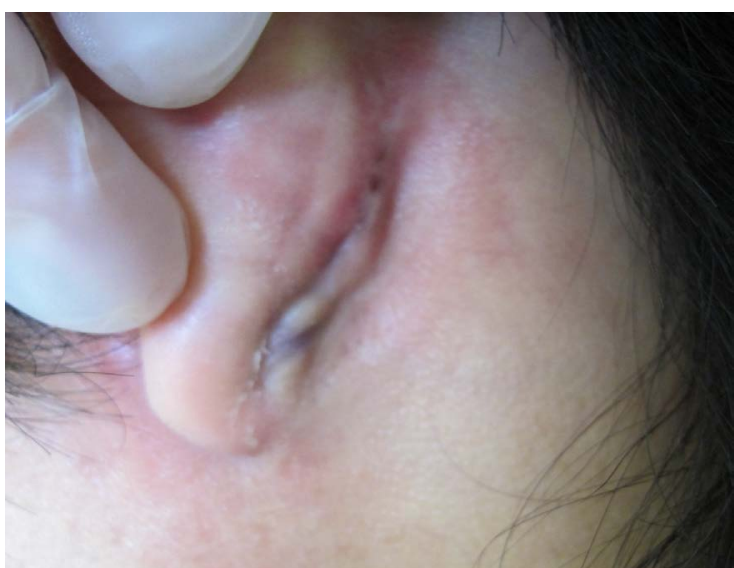

Figure 5: A sinus fistula in the postauricular area was observed before treatment (Case 20).

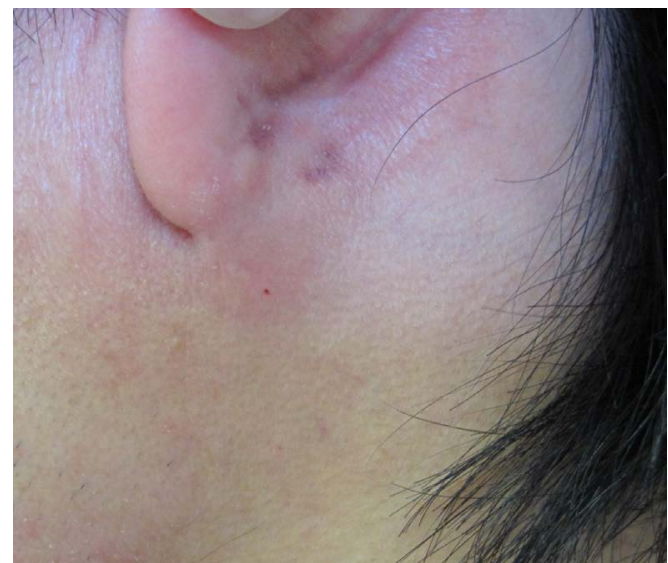

Figure 6: After treatment, the sinus fistula disappeared completely (Case 20).

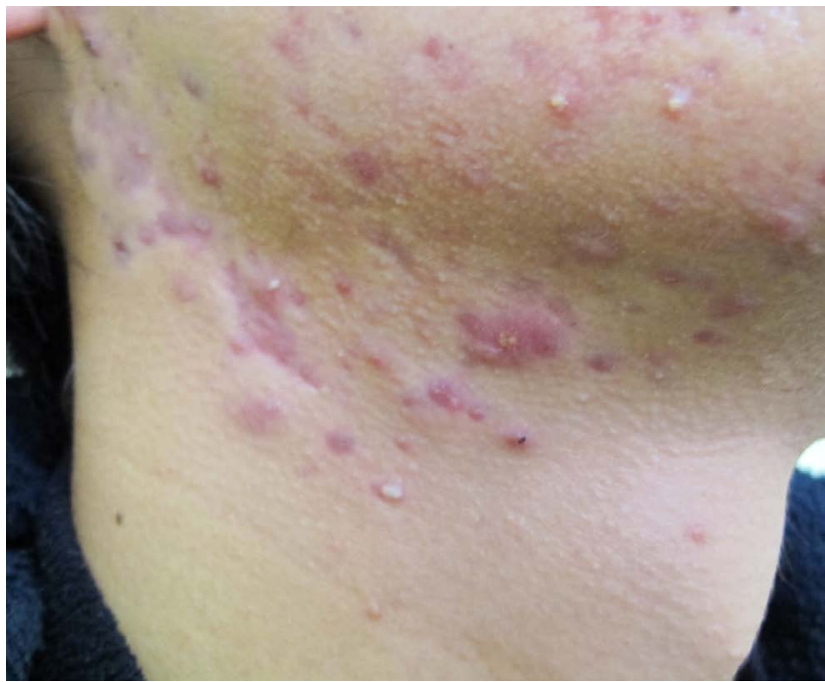

Figure 7: Elevated multiple hypertrophic scars with redness were observed on the neck in Case 15. 
Citation: Kurokawa I (2017) Successful Adjuvant Alternative Treatment with Saireito (Japanese Herbal Medicine) for Nodulocystic Acne. J Nutr Disorders Ther 7: 215. doi: 10.4172/2161-0509.1000215

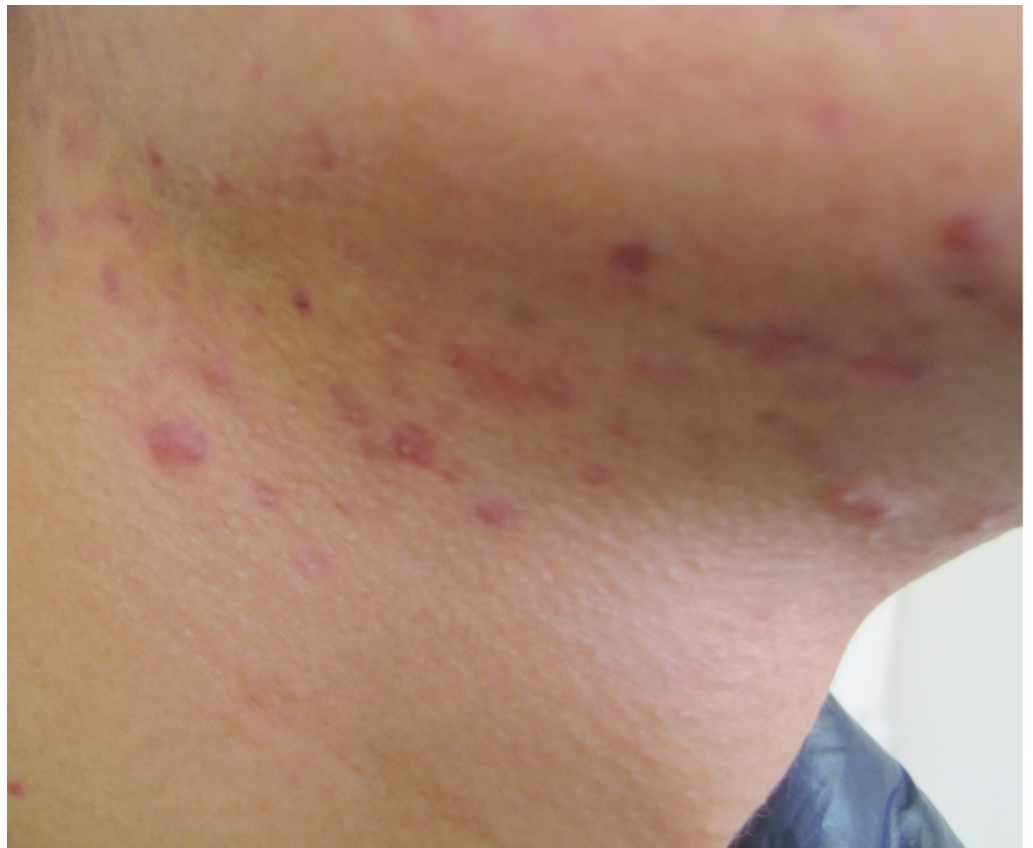

Figure 8: After treatment, the hypertrophic scars were remarkably improved in Case 15.

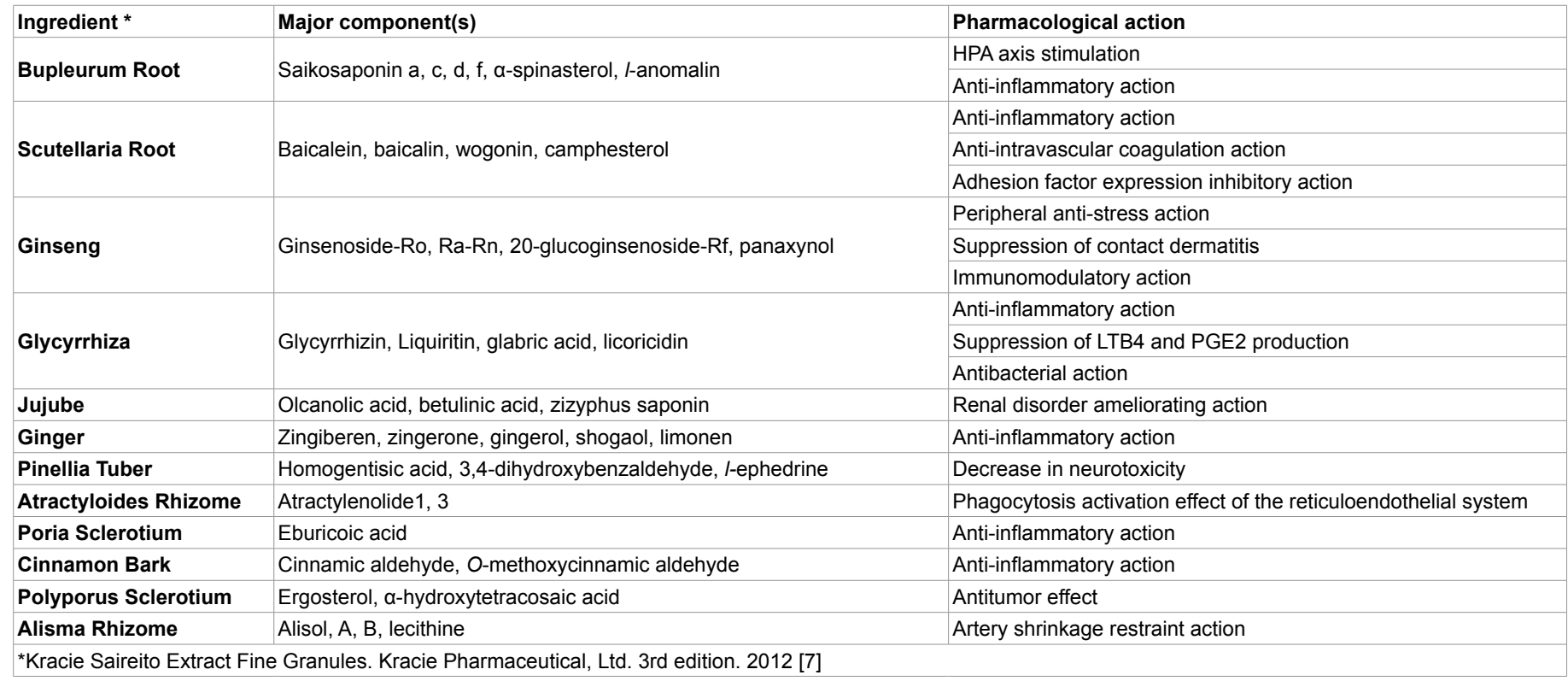

Table 2: Ingredient and Mode of action of Saireito.

Concerning adverse reactions, slightly elevated liver enzymes (ALT: alanine aminotransferase) were observed in two cases. Tremors of the hand and foot were observed in one case; after the Saireito was discontinued, the symptoms resolved. No other clinical symptoms were observed during the study, and no severe adverse reactions were observed in other cases.

Blood cell counts, liver enzymes, renal function, electrolytes, and C-reactive protein levels in 13 cases were within normal limits.

\section{Discussion}

Nodulocystic acne is a therapy-resistant type of acne. The cysts can develop from closed comedo by dilatation of the follicular epithelium. Once a cyst ruptures, macrophages can phagocytize foreign bodies like hair and keratin within the dermis. The ruptured cysts produced foreign body granulomas that result in nodules.

For a few nodules and subcutaneous induration in acne vulgaris, oral antimicrobials are recommended as $\mathrm{C} 1$ treatment for inflamed cysts and subcutaneous induration, while an intralesional topical corticosteroid injection is recommended as B treatment by the JDA guideline [3]. Males were predominantly affected in nodulocystic acne in this study. 
watery diarrhea and acute gastroenteritis [6]. The detailed ingredient description and mode of action of Saireito is shown in Table 2 [7]. It is also effective for polycystic ovary syndrome, PAPA syndrome, rheumatoid arthritis, Crohn's disease, and ulcerative colitis (Th1 predominant disease) [8]. In this study, hypertrophic scar was improved by oral Saireito in one case. The overexpression of transforming growth factor-beta (TGF- $\beta$ ) can lead to the formation of hypertrophic scars and keloids [10]. Saireito can inhibit fibroblast proliferation due to TGF- $\beta$, thereby improving scar formation [11]. Saireito is clinically effective for the treatment of acne scars [12].

The etiology of sinus fistula formation in acne is unclear [13]. The authors stated that the sinus includes corneocytes, hairs, serum, bacteria, inflammatory cells, and epitheloid granuloma [14] and that treating sinus fistula is difficult [13]. Intralesional corticosteroid injections, isotretinoin, and liquid nitrogen are not always effective [13]. In this study, Saireito was effective for sinus tract in one case.

Several reports such as Keigai-rengyo-to [14] and Seijo-bofuto [14] and Jumihaidoku-to [15] have shown that Kampo (Japanese Chinese herb) is an effective acne treatment.

Acne is a multifactorial disease that involves an increased sebum excretion rate, hormonal factors, follicular hyperkeratinization, the proliferation of bacteria such as Propionibacterium acnes, and cytokine-related inflammation [16]. Based on the above-mentioned results, oral Saireito showed remarkable improvement for nodulocystic acne with fewer adverse reactions. Thus, our findings suggest that Saireito can be a candidate alternative adjuvant for the treatment of nodulocystic acne. Clinical trials are necessary to clarify the availability and safety of Saireito in nodulocystic acne.Further investigation is needed to elucidate the pharmacological mechanism and clinical effects of Saireito alone and acne pathogenesis.

\section{References}

1. Peck G, Olsen TG, Yoder FW et al. (1979) Prolonged remissions of cystic and conglobate acne with 13-cis-retinoic acid. New Engl J Med 15: 329-333.
2. Peck GL, Olsen TG, Butkus D, Pandya M, Arnaud-Battandier J, et al. (1982) Isotretinoin versus placebo in the treatment of cystic acne. A randomized double-blind study. J Am Acad Dermatol 6: 735-745.

3. Hayashi N, Akamatsu H, Iwatsuki K (2016) Guideline for the treatment of acne vulgaris in Japanese Dermatological Association. J Dermatol 126: 1045-1086.

4. Oguchi M, Akamastu H, Nishijima S (1987) Treatment with metronidazole for acne. Hifu (Skin Research) 29: 995-1000.

5. Wakabayashi M, Fujii N, Fujimoto N, Tanaka T (2011) Cystic acne successfully treated with diaminodiphenylsulfone. J Dermatol 38: 502-504.

6. Makino T (2014) Anti-inflammatory effects by Saireito. Science of Kampo Medicine 38: 114-117.

7. Kracie Saireito (2012) Extract Fine Granules. Kracie Pharmeceutical Ltd. 3rd edition.

8. Kurokawa I (2015) Successful treatment with Saireito for cystic acne. Phil Kampo 57: 24-25.

9. Jeremy AH, Holland DB, Roberts SG, Thomson KF, Cunliffe WJ (2003) Inflammatory events are involved in acne lesion initiation. $\mathrm{J}$ Invest Dermatol 121: $20-27$.

10. Zouboulis C, Bettoli V (2015) Management of severe acne. Br J Dermatol 172 27-36.

11. Sohen H, Tanabe A, Fujita D, et al. (2015) The inhibitory effect of Sairei-to on hypertrophic scar formation through TGF- $\beta$. Hankonn Keloid Chiryou J 9: 1-7.

12. Huh W (2014) Clinical evaluation with Saireito for acne scar. Phil Kampo 48 : 20-22.

13. Jansen T, Lindner A, Plewig G (1995) Draining sinus in acne and rosacea. A clinical, histopathologic and experimental study. Hautarzt 46: 417-420.

14. Higaki S, Hasegawa Y, Morohashi M, Takayoshi Y (1995) The correlation of Kampo formulations and their ingredients on anti-bacterial activities against Propionibacterium acnes.J Dermatol 222: 4-9.

15. Nomoto M (2017) How to use Kampo drug for cosmetic dermatologists. Aesteic Dermatology 26: 307-315.

16. Kurokawa I, Danby FW, Ju Q, et al. (2009) New developments in our understanding of acne pathogenesis and treatment. Exp Dermatol 18: 821-832. 